\title{
Assessment of plant diversity for threat elements: A case study of Nargu wildlife sanctuary, north western Himalaya
}

\author{
Pankaj Sharma*, S.S. Samant and Manohar Lal \\ G.B. Pant National Institute of Himalayan Environment and Sustainable Development, Himachal Unit, Mohal- \\ Kullu-175126, H.P., India
}

Received: 12/07/2016; Accepted: 16/02/2017

\begin{abstract}
Biodiversity crisis is being experienced throughout the world, due to various anthropogenic and natural factors. Therefore, it is essential to identify suitable conservation priorities in biodiversity rich areas. For this myriads of conservational approaches are being implemented in various ecosystems across the globe. The present study has been conducted because of the dearth of the locationspecific studies in the Indian Himalayas for assessing the 'threatened species'. The threat assessment of plant species in the Nargu Wildlife Sanctuary (NWS) of the northwest Himalaya was investigated using Conservation Priority Index (CPI) during the present study. CPI was calculated using cumulative values of various qualitative and quantitative attributes viz., habitat specificity, population size, distribution range, use values, extraction, nativity and endemism of the taxa. Out of a total of 733 species recorded in the area, 102 species (20 Trees; 14 Shrubs; and 68 Herbs) belonging to 82 genera and 54 families were identified as threatened. The study revealed that 8 species 'Critically Endangered', 17 species 'Endangered' and 77 species 'Vulnerable'. These species must be monitored and actively managed with appropriate conservation strategies including periodical assessment of populations using standard ecological methods in order to conserve the high biodiversity in the NWS.
\end{abstract}

Keywords: Conservation, endemism, Himalaya, nativity, threatened.

\section{INTRODUCTION}

Biodiversity is one of the major livelihood options as it provides many ecosystem services including provisioning, regulating, supporting and cultural (MA, 2005). Several elements of biodiversity (e.g. species, habitats and ecosystem services) are in decline as the human domination of the earth continues to increase (Groombridge and Jenkins, 2000; Hilton-Taylor, 2000; GEO3, 2002). Major threats to ecosystems and biodiversity are habitat fragmentation and its losses, over exploitation, invasions of non-native species, global climate change (IUCN, 2003) and disruption of community structure (Novasek and Cleland, 2001). As a result of the anthropogenic pressure, the plant extinction rate has reached to137 species per day (Mora et al., 2011; Tali et al., 2015). At present, the rapid loss of species is estimated to be between 1,000-10,000 times faster than the expected natural extinction rate (Hilton-Taylor, 2000). Under the current scenario, about $20 \%$ of all species are likely to go extinct within next 30 years and more than $50 \%$ by the end of $21^{\text {st }}$ century (Myers, 1993). The most direct measure of the threats to the biodiversity can be derived from the assessments of conservation status of the species. The IUCN Red List of Threatened Species, categorize species that have a high probability of extinction in the future as 'Critically Endangered', 'Endangered' or 'Vulnerable'. The degradation and fragmentation of $>70 \%$ of the original habitats have placed Himalaya in the list of Global Biodiversity Hotspots, where only 25\% of the original habitats are remaining unaffected due to various natural and anthropogenic pressures (Mittermeier et al., 2004). The Convention on Biological Diversity Summit (June, 1992) signaled the global recognition of the alarming loss of biodiversity. Since then, various studies have been conducted to explore and identify the threatened plants of the world (Singh, 2002). As far as the matter of assigning the threat status to a species is concerned, a species' global conservation status, is not necessarily the same as the conservation status on a regional scale. However, it is often argued that status of a particular species may vary from region to region, thus local needs and threats should also be considered while deciding conservation priorities (Silva and Albuquerque, 2005; Gauthier et al., 2010). Some species that 
are threatened on the global scale may not be threatened at a regional scale, and species that are not threatened on a global scale might be threatened in some parts of their range (Gardenfors et al., 2001). Moreover, knowing the regional status of species is important as the loss of population and genetic diversity has become a major concern in the present scenario (Grammont and Cuaron, 2006). When a species is protected at the regional level, conservation of its genetic diversity is promoted (Hunter and Hutchinson, 1994). Regional scale extinction of one species can trigger a cascade of extinctions, causing a change in species structure, composition and in ecosystems processes (Lundberg et al., 2000). This deviation in the threat status from region to region clearly suggests that local situation must be taken into account while setting conservation priorities. Therefore, growing awareness on the importance and high rates of loss biodiversity make it imperative to rapidly assess and conserve biodiversity, both at regional and global levels. Since IUCN categorization only is not sufficient for formulating the local and regional conservation strategies as usually it has a larger area under its influence. Hence, there is need of collecting and maintaining precise and accurate information that can be used for the area specific prioritization of species. Many researchers have studied the threatened plants in Indian Himalayan Region (IHR) (Pangtey and Samant, 1988; Samant et al.,1998; Pandey and Well, 1997; Kala et al., 1998; Dar and Naqshi, 2001; Badola and Pal, 2003; Ved et al., 2003; Rana and Samant, 2010; Banerji and Basu, 2011; Goraya et al., 2013 and Tali et al., 2015). Various studies have been carried out in the protected and unprotected areas of Himachal Pradesh (Lal, 2007; Rana and Samant, 2010; Sharma, 2013).

Although, there has been an increasing recognition of the significance of the wider landscape and community conservation approaches, the central role of protected areas in conservation is still widely recognized (Monzón et al., 2011; Zomer et al., 2015). Only a few studies have been carried out in the protected areas using different attributes of rarity i.e., habitat preference, population size, nativity/ endemism, anthropogenic pressure and distribution range (Rawal and Dhar, 1997; Samant, 1999; Joshi and Samant, 2004; Kala, 2004; Samant and Joshi, 2005;Lal, 2007; Rana and Samant, 2010, etc.). Although located on the northwestern slopes of Himalaya the threat assessment of all the species of Nargu Wildlife Sanctuary has not been carried out so far. Therefore, the present studyattempts to assess the threat categories of species, study their distribution pattern and suggest conservation options considering the results.

\section{MATERIALS AND METHODS}

\section{Study area}

The study was conducted from 2010 to 2015 in Nargu Wildlife Sanctuary (NWS) $\left(31^{\circ} 46^{\prime} 36^{\prime \prime}\right.$ to $32^{\circ} 04^{\prime} 00^{\prime \prime} \mathrm{N}$ Latitudes and $76^{\circ} 50^{\prime} 00^{\prime \prime}$ to $77^{\circ} 04^{\prime} 30^{\prime \prime}$ E Longitudes) which is located in Chuhar valley of Mandi district of Himachal Pradesh (Figure 1). The Sanctuary, which was declared in 1972, is surrounded by Kullu, Mandi, Jogindernagar and Palampur Forest Divisions. It covers an area of over $278.38 \mathrm{~km}^{2}$ with an altitudinal range, $970-4,052 \mathrm{~m}$ asl.

The whole area is mainly mountainous with undulating low hills in the west and steep to precipitous mountains in the north and east. There are numerous high ridges, deep gorges and cliffs and narrow valleys. The climate of the area is sub-tropical, temperate, sub-alpine and alpine and consists of summer (mid April-mid June), rainy (mid June-September) and winter (OctoberMarch) seasons. The area receives precipitation both in the form of snowfall and rainfall. About $80 \%$ of the precipitation is received by southwest monsoon and the rest by western disturbances. However, the Sanctuary is now rationalized as per notification (No. FFE-B-F(6)16/1999-Nargu; Dated, 29 November 2013) of the Government of Himachal Pradesh, Department of Forests. The study was conducted in the non-rationalized area as it was proposed earlier to this notification. 


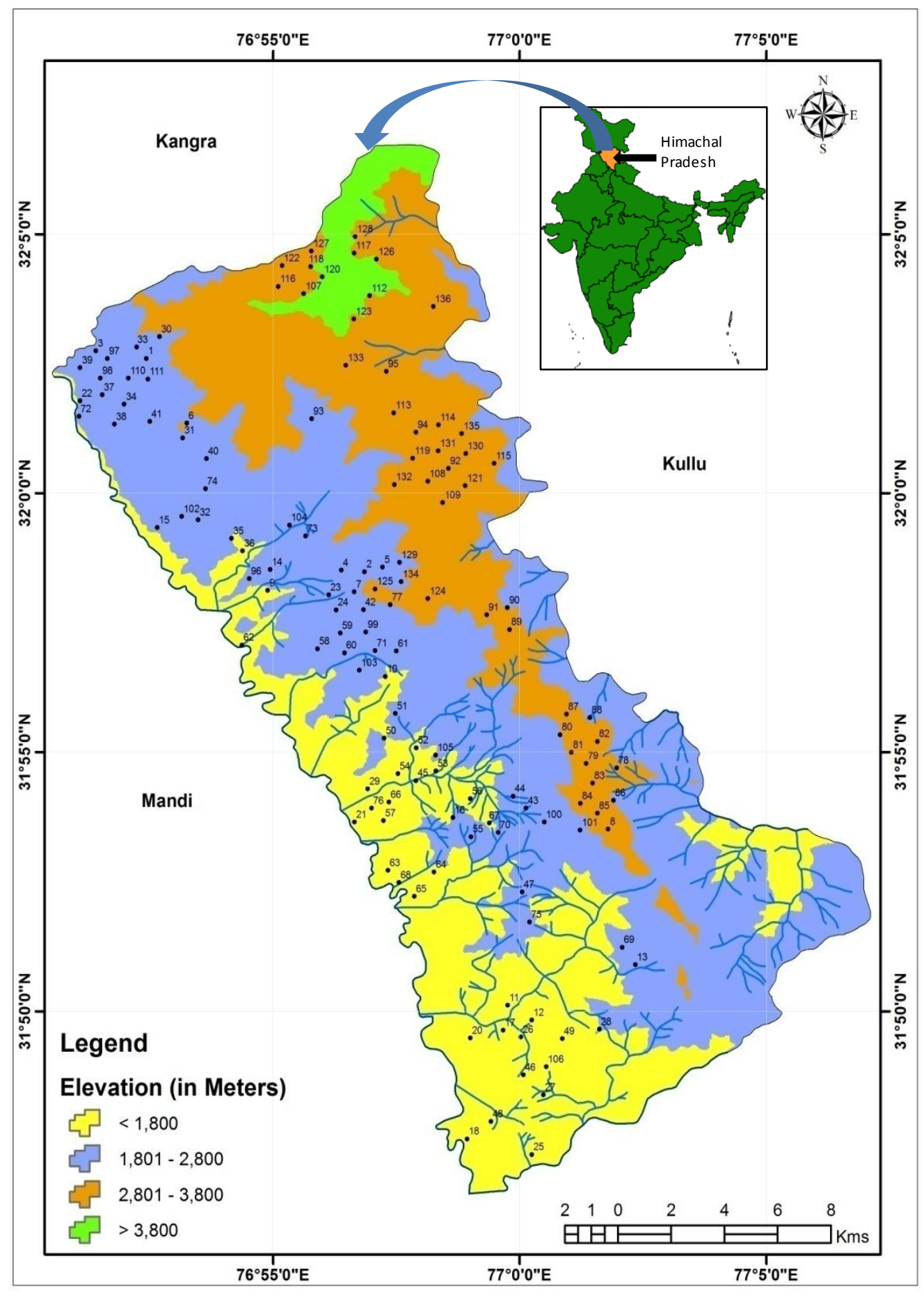

Figure 1: Elevation map of the NWS showing sampled sites (1-136).

\section{Sampling}

Number of surveys were conducted between 970 $-4,052 \mathrm{~m}$ in NWS in all the seasons 2010 to 2015 to investigate the stated objectives. Random sampling was done for the qualitative analysis of vegetation in all the seasons (summer, rainy and winters) for the floristic surveys.
However, for the quantitative assessment for threat categories, the sampling was conducted during July to September each year. A total of 136 sites were sampled in NWS where, 111 sites were in forests and 25 sites were in alpine zones. In the forest zone, a plot of $50 \times 50 \mathrm{~m}$ was laid in each site. For shrubs, 20 quadrats of $5 \times 5 \mathrm{~m}$, and for herbs, 20 quadrats of $1 \times 1 \mathrm{~m}$ were randomly 
laid within the same plot. Shrubs were considered as the woody species having several branches arising from their bottom (Saxena and Singh, 1982). For assessing the alpine vegetation in each site, a $20 \times 20 \mathrm{~m}$ plot was laid and within it 10 quadrats of $5 \times 5 \mathrm{~m}$ for shrubs and 20 quadrats of $1 \times 1 \mathrm{~m}$ for herbs were randomly laid. Standard ecological methods (Saxena and Singh, 1982; Singh and Singh, 1992; Dhar et al., 1997; Joshi and Samant, 2004; Samant and Joshi, 2005) were used for the collection and analysis of the data viz., population of the species etc. The Global Positioning System (Make; Garmin GPSmap76CSx) is used for recording the georeferences, altitude and aspect etc.The record of the indigenous uses is mostly based on the interviews done with the people during the surveys, however in the case of medicinal plants information on indigenous uses were updated with the help of relevant secondary information (Jain, 1991; Samant and Palni, 2000; Samant et al., 2007). The interviews were conducted mostly on individual-basis, except in some cases, where several people participated at the same time. Interviews were done with the help of open and semi structured questionnaires.

The habitats in the sanctuary were identified based on the physical characters and dominance of vegetation. Moist and humus rich shady sites were considered as moist habitat while low percent of the same as dry habitat. The sites facing high anthropogenic pressure were considered as degraded habitats and sites having single large rock as rocky whereas others as used for camping by the shepherds or grazers as camping sites. The ones having $>50 \%$ boulders of the ground cover were considered as bouldary and others nearby the water streams as riverine. The sites having submerged vegetation or having excess moisture are considered as marshy, alpines pastures as dry or grasslands as per the moisture content in the soil and others having $>50 \%$ of shrubs were considered as shrublands.

\section{Data analysis}

\section{Vegetation data}

The nativity of a species denotes its origin or first record (Samant et al., 1998) and has been identified (Anonymous, 1883-1970; Samant and Dhar, 1997; Samant et al.,1998, 2000; http://www.ipni.org). In case of Pteridophytes, the species distributed in the Himalayan Region have been considered as native to the region whereas the remaining species as non-natives. Endemism of the species has been identified based on distribution of the species (Dhar and Samant, 1993; Samant et al.,1998, 2000; Samant and Dhar, 1997; Samant, 1999). The species restricted to the Himalayan region have been considered as endemic.

For knowing the regional threat status of a particular species, Conservation Priority Index (CPI) was calculated to categorize species under different threat categories in the NWS (Rana and Samant, 2010). The cumulative values of the various attributes viz., habitat specificity, population size, distribution range, use values, extraction, nativity and endemism of the taxa were used to calculate the CPI for each species. To calculate CPI, the number of parameters used for each species was given grade/marks, maximum 10 point; moderate 6 points and minimum 2 points (Table 1). Therefore, the lowest grade minimum score i.e., 2 was assigned instead of zero. The species fulfilling all the attributes in the highest grade resulted in highest cumulative values and one which falls in the lowest for each attribute resulted in lowest cumulative values. The highest marks possible was 60, meaning all the characteristics were present and satisfactory for that particular taxa. The species having $\geq 60 \%$ of the total CPI were considered as 'Critically Endangered'; 55-59\% as 'Endangered'; 50-54\% as 'Vulnerable'; and $45-49 \%$ as Near Threatened, whereas $<45 \%$ were considered as Least Concern (Rana and Samant, 2010).

The regionally threatened species of the NWS were compared to the threatened species of State and globe following (Nayar and Sastry, 1987-90; Ved et al., 2003; Rana and Samant, 2010; Goraya et al., 2013). The species, that was observed outside the sampled sites were also considered for categorization.

\section{RESULTS}

\section{Threat Categorization and Species Diversity}

The present study recorded 733 species of vascular plants i.e., angiosperms (113 families, 366 genera and 680 species), gymnosperms (3 families, 6 genera and 9 species) and pteridophytes (16 families, 25 genera and 44 species). Of the total species, 74 species were trees, 125 shrubs, 490 herbs and 44 pteridophytes. Among these, 102 species (20 Trees; 14 Shrubs; and 68 Herbs) belong to 82 
genera and 54 families have been identified as 'threatened' from the NWS (Table 2). Out of the total, 66 species were cited in the sampled sites.

In the present study, 8 species were categorized as Critically Endangered, 17 species as Endangered; 77 species as Vulnerable, 158 species as Near Threatened and other 473 species as least concerned (Table 2). Species have been categorized as Critically Endangered (3 spp.); Endangered (13 spp.) and Vulnerable (29 ssp.) for Himachal Pradesh using IUCN criteria. Critically Endangered (1 spp.), Endangered (4 spp.) and Vulnerable (4 spp.) were identified according to the global threat categories.

\section{Altitudinal distribution}

In general maximum number of species (i.e., 546 spp.) was recorded in the altitudinal zone, 1801$2800 \mathrm{~m}$. The diversity decreased with the increasing altitude. Similarly, along an altitudinal gradient, the maximum threatened species (68 spp.) were distributed in $1801-2800 \mathrm{~m}$ zone, followed by 2801- $3800 \mathrm{~m}$ (56 spp.) zone (Figure 2).

\section{Site Wise Distribution}

Among the 136 sites at NWS, a total of 589 species (Trees: 54; Shrubs: 85 and Herbs: 450) have been recorded. 514 species (Trees: 55; Shrubs: 83 and Herbs: 376) were reported from the forest zone and 282 species (Shrubs: 14; Herbs: 268) from the alpine zone. Eighty two (82) species were present in a single site, sixty four species (64) in two sites, fifty four species (54) in three sites, fifty eight species (58) in four sites, fifty two species (52) in five sites, twenty six species (26) in six sites and twenty three species (23) in seven sites. The rest of the 230 species were reported in more than seven sites.

Table 1: Attributes used for Threat Categorization of Species in NWS.

\begin{tabular}{lllllll}
\hline \hline $\begin{array}{l}\text { Grade/ } \\
\text { marks }\end{array}$ & $\begin{array}{l}\text { Altitudinal } \\
\text { Range }(\mathbf{m})\end{array}$ & $\mathbf{H}$ & $\begin{array}{l}\text { Use } \\
\text { Values }\end{array}$ & $\begin{array}{l}\text { Population } \\
\text { Size/locations }\end{array}$ & $\begin{array}{l}\text { Native \& } \\
\text { Endemic }\end{array}$ & Extraction \\
\hline 10 & $<500$ & 1 & $>4$ & $<50$ Ind or 2 locations & Native \& Endemic & Commercial \\
6 & $500-1000$ & $2-3$ & $3-4$ & $50-250$ or 3-5 locations & Native/Endemic & Self-Use \\
2 & $>1000$ & $>3$ & $<3$ & $>250$ Ind or >5 locations & Non-native & No Extraction \\
\hline
\end{tabular}

Abbreviations Used: H= No. of Habitat (s); Ind= No. of individuals

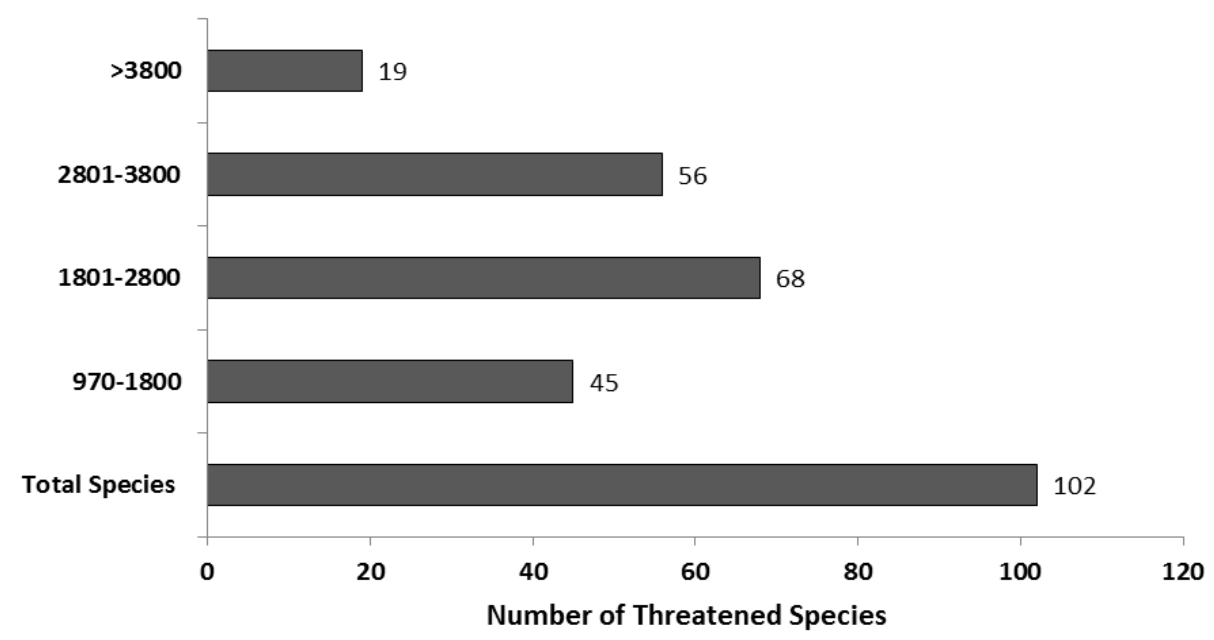

Figure 2: Altitudinal distribution of threatened plant species in NWS. 


\section{Distribution of plant species among different Habitat}

Of the total species recorded, 14 were habitat specific, 176 were recorded in two habitats, 308 in three habitats and 235 in more than three habitat types. Of the threatened species reported, habitat wise distribution of the species in the forest and alpine zones of the sanctuary had 7 species only distributed in one habitat, 28 species in two habitats whereas 67 species were distributed in 3 or $>3$ habitats. Among the species, Melothria heterophylla (6 habitats), Salvia lanata, Ribes alpestre, Lagotis cashmeriana, Juglans regia and Dioscorea deltoidea (5 habitats, each), Vincetoxicum hirudinaria, Viburnum mullaha, Trichosanthes tricuspidata, Thamnocalamus spathiflora, Swertia ciliata, Swertia angustifolia, Rhodiola heterodonta, Phegopteris connectilis, Olea ferruginea and Cinnamomum tamala (4 habitats, each) were distributed among maximum number of habitats (Table 2).

\section{Nativity and endemism}

From the total recorded species, 414 species were native to the Himalayan Region, while the remaining species were exotics. Twelve species were endemic and 152 species near endemic to the IHR.Whereas among the threatened and near threatened species 184 species were native, 76 exotics, 10 endemic and 73 near endemic to the Indian Himalayas. However, of the quantified species about $68.3 \%$ were native to the Himalaya. About $20.3 \%$ of the total and $29.8 \%$ of the native species were near endemic and $1.9 \%$ of the total and $2.7 \%$ of the natives were endemic to the IHR.

\section{Extraction of species}

A total of 552 species were identified as economically important plants (belonging to 120 families and 332 genera). These species were used as medicine (371 spp.), wild edible/food (131 spp.), fodder (206 spp.), fuel (87 spp.), fiber (12 spp.), religious (28 spp.), timber (14 spp.), making agricultural tools (16 spp.) and for miscellaneous domestic and commercial purposes.

Among threatened and near threatened species, 32 species were extracted for commercial purposes while 129 species extracted by inhabitants for their own use. For example, Aconitum heterophyllum, Aesculus indica,
Allium humile, Angelica glauca, Arnebia benthamii, Cedrus deodara, Dactylorhiza hatagirea, Dioscorea deltoidea, Habenaria edgeworthii, Juniperus indica, Jurinella macrocephala, Malaxis muscifera, Picea smithiana, Picrorhiza kurrooa, Podophyllum hexandrum, Rheum australe, Rhododendron arboreum, Taxus baccata subsp.wallichiana, Toona ciliata, Valeriana jatamansi etc. are valued for various commercial purposes.

\section{Population size and site representation}

Among the quantified plants $32 \%$ species (190 spp.) had only < 50 individuals in the sampled sites, 37\% (218 spp.) with population size of 51250 individuals and $31 \%$ (181 spp.) with population size $>250$ individuals. One hundred forty four species were not represented in any sampled sites and they were considered as species with low population size.

Among the threatened species, 28 species had only $<50$ individuals in the sampled sites and 28 species with population size of 51-250 individuals and seven specieshad population size of $>250$ individuals.

\section{DISCUSSION}

Ecologists observe that the massive extinction of the species is occurring in high altitudinal areas like the Himalaya that have high biological diversity including many endemic species. At present, biodiversity crisis is being experienced throughout the world, therefore suitable conservation actions need to be set up for optimal use of limited resources. Studies indicate that we have altered approximately half of the habitable surface of the earth (Daily, 1995; Singh, 2002). Therefore, myriads of conservational approaches are being implemented in various ecosystems across the globe. Unfortunately, none of the available methods of setting conservation priorities are generally accepted, as their data requirements are too strict, scientifically unsound, or are too complex for the usage by decision makers (Schmeller et al., 2008). Majority of the studies of setting the priorities for conservation of the plant species have been carried out using qualitative observations only. The IUCN status of the species is based on the published flora, reports and research papers which are typically based on qualitative observations. In addition, threat assessments were based on opinion and perception of specialists during workshops and 
meetings (Ved et al., 2003, 2005; Goraya et al., 2013). Though, such exercises help in prioritizing species for conservation and management, they do not provide the authentic information on the actual status of the species, which is only possible through ground validation. Therefore, location specific studies are essential to set conservation priorities. For this purpose, assessment of the status of species using qualitative and quantitative attributes has only been suggested by few workers (Samant et al., 1996; Airi et al., 1997). Likewise, Rawal and Dhar (1997) have attempted to estimate the sensitivity of the timberline flora of Kumaun Himalaya based on habitat specificity, distribution range and population size, but others highlight the necessity of further thorough investigation (Rana and Samant, 2010).

The plant species are facing natural and anthropogenic threats at the NWS. The habitats of most of these threatened species fall within the extensively grazed alpine meadows and subalpine zones. Animals which browse leaves and reproductive parts of plant species damage their flowering spikes and thereby restrict their population size and distribution (Ganie and Tali, 2013). Most of the individuals of different species were not able to produce seeds because the flowers are extensively grazed by livestock threatening their long-term survival.

The population size, habitat specificity, nativity and endemism, distribution range and use pattern play a significant role in decision making of the status of a species in particular area. In the present study, threat assessment of floristic diversity for the NWS has been carried out for the first time. On the basis of cumulative values (i.e., CPI) of conservation attributes, species have been categorized. The higher CPI indicates the need for a greater level of attention to local strategies for conservation and management. Categorization of 8 species as Critically Endangered, 17 species as Endangered; 77 species as Vulnerable and 158 species as Near Threatened indicated the high degree of anthropogenic pressure in the area. Existence of species such as Allium humile, Dactylorhiza hatagirea, Fritillaria roylei, Jurinella macrocephala, Aconitum heterophyllum, Angelica glauca, Dioscorea deltoidea, Malaxis muscifera, Picrorhiza kurrooa and Paris polyphylla were highly threatened in the NWS as well as globally hence they have high conservation importance. Altering the land use, climate change, nitrogen deposition, biological exchange and atmospheric carbon dioxide are the major factors contributing towards change in biodiversity. Moreover, climate change is not been considered as a major threat for plants and therefore it is less important than the change in land use types (Sala et al., 2000).

Pressure of human overpopulation and climate change interfere with the natural ecosystems and introduction of non-native species increase pressure on survival of the native species (Vitousek, 1990; Levine et al., 2003; Serrill, 2006). Anthropogenic activities such as extraction of resources by humans, tourism and livestock grazing spread non-native species into the forested areas. Disturbance leads to the invasion of non-native species (Huston, 1994). Hence, there seems is a strong need for increased surveillance, early detection, and eradication of non-native and invasive species from the area as these out-compete the natives and destabilize the local ecosystem.

Altitudinal zone, $1801-2800 \mathrm{~m}$ had the highest richness of threatened species. This may be due to heavy biotic pressure on this zone leading to habitat degradation and ultimately to extinction of the species. Besides, occurrence of 9 species in only one site and 8 species in two sites indicated the early extinction of these species if the habitat degradation and anthropogenic activities continue to operate. Similarly, occurrence of 7 species only in one habitat and 28 species in two habitats indicated their high habitat preferences. Such species have less chances of proliferation than the species with wide range of habitats (Samant et al., 1996).

Species such as Valeriana jatamansi (35 sites, 3 habitats), Bergenia ciliata (29 sites, 2 habitats), Thamnocalamus spathiflora (21 sites, 4 habitats), Hedychium spicatum (20 sites, 3 habitats), Viburnum mullaha (19 sites, 4 habitats), Parnassia nubicola (12 sites, 4 habitats), and Symplocos chinensis (12 sites, 2 habitats), Swertia angustifolia (11 sites, 4 habitats) and Skimmia laureola (11 sites, 3 habitats), etc., had wide range of distribution and habitat preferences, due to over-exploitation for various purposes and habitat degradation, these species too facing high degree of threat. Amongst habitats, shady moist, rocky and dry forest habitats supports maximum number of 
threatened species, hence these require priority for conservation.

However, the distribution of the preferred economically valuable species in the sanctuary indicated their availability in the area, but continuous exploitation of these species may lead to their population depletion. Low density of the preferred species indicated high anthropogenic pressure, which may lead to the extinction of these species in near future and replaced by the other less economically important species. This may too affect the regional ecology because imprudent use of plant resources is a direct threat to biodiversity and the continued proper functioning of mountain ecosystems (Sharma et al., 2010; Tarraso'n et al., 2010).

Nevertheless, the protected area systems are not entirely safe, thus the threatened species have no guarantee to remain safe (Krupnick, 2013). To maintain the viability of a threatened plant population in a protected area, the species must not suffer from the 'benign neglect' approach to conservation (Heywood and Iriondo, 2003). Species within protected areas must be monitored and actively managed. For long-term resilience of landscapes of the NWS that remain under cultivation or grazing, it is more important to create corridors of forest cover to encourage the dispersal agents that use them and prohibit any anthropogenic activity in the area. In addition to the above, an appropriate conservation strategy by periodical assessment of population and habitats' monitoring of the threatened species using standard ecological methods are suggested.

\section{ACKNOWLEDGEMENTS}

The Director of G.B. Pant National Institute of Himalayan Environment and Sustainable Development, Kosi-Katarmal, Almora, Uttarakhand, India is acknowledged for encouragement and providing the essential infrastructural and financial facilities. The stakeholders of the area are thanked for the cooperation and information they provided throughout the study period. Anonymous reviewers are thanked for their critical remarks and suggestions.

\section{REFERENCES}

Airi, S, Rawal, R. S., Dhar, U. and Purohit, A. N. (1997). Population studies on Podophyllum hexandrum Royle-a dwindling medicinal plant of the Himalaya. Plant Genetic Resources 110: 2934.

Anonymous. (1883-1970). Index Kewensis Plantarum PhanerogamarumVol. 1-2 (1883-1885) and 15 Suppl. (1886-1970). Clarendron Press, Oxford.

Badola, H. K. and Pal, M. (2003). Threatened medicinal plants and their conservation in Himachal Himalaya. Indian Forester 129: 55-68.

Banerji, G. and Basu, S. (2011). Sustainable Management of the Herbal Wealth of the Himalayas: prioritizing biodiversity for conservation and development. Pre-Congress Workshop of 1st Indian Forest Congress, HFRI. Sub-theme: Ecosystem Resilience and Forest Biodiversity.

Daily, G. C. (1995). Restoring Value to the World's Degraded Lands. Science 269: 350354.DOI:10.1126/science.269.5222.350.

Dar, G. H., Naqshi, A. R.(2001). Threatened flowering plants of Kashmir Himalaya- A checklist. Oriental Science, 6: 23-53.

Dhar, U., Rawal, R. S. and Samant, S. S. (1997). Structural diversity and representativeness of forest vegetation in a protected area of Kumaun Himalaya, India: implications for conservation. Biodiversity and Conservation6: 1045-1062.DOI: 10.1023/A:1018375932740.

Dhar, U. and Samant, S. S.(1993). Endemic diversity of Indian Himalaya I. Ranunculaceae and II. Paeoniaceae. Journal of Biogeography 20: 659668.DOI:10.2307/2845521.

Ganie, A. H. and Tali, B. A. (2013).Vanishing medicinal plants of Kashmir Himalaya. Indias. Available http://www.greaterkashmir.com/news/gkmagazine/vanishing-medicinal-plants-ofkashmir-himalaya/153598.html (Date accessed: September 2015)

Gardenfors, U., Taylor, C. U., Mace, G. M. and Rodriguez, J. P.(2001). The application of IUCN red list criteria at regional levels. Conservation Biology 15: 1206-1212.DOI: 10.1046/j.15231739.2001.00112.x.

Gauthier, P., Debussche, M. and Thompson, J. D.(2010). Regional priority setting for rare species based on a method combining three criteria. Biological Conservation 143(6): 15011509.DOI: 10.1016/j.biocon.2010.03.032.

GEO3. (2002).Global Environmental Outlook: Past, Present and Future Perspectives. UNEP and Earthscan, London, UK.

Goraya, G. S., Jishtu,V., Rawat, G. S.and Ved, D. K.(2013). Wild Medicinal Plants of Himachal Pradesh. In: An Assessment of their conservation status and management prioritization, Himachal Pradesh. Himachal Pradesh Forest Department, Shimla.

Grammont, P. C. D., Cuaron, A. D. (2006). An evaluation of threatened species categorization systems used on the American Continent. 
Conservation Biology 20(1): 14-27.DOI: 10.1111/j.1523-1739.2006.00352.x.

Groombridge, B. and Jenkins, M. D.(2000). Global Biodiversity: Earth's Living Resources in the 21st Century. World Conservation Press, Cambridge, UK.

Heywood, V. H. and Iriondo, J. M.(2003). Plant conservation: Old problems, new perspectives. Biological Conservation 113:321-335.DOI: 10.1016/s0006-3207(03)00121-6.

Hilton-Taylor, C. (2000). The IUCN Red List of Threatened Species. IUCN, Gland, Switzerland and Cambridge, UK.

Hunter, M. L. and Hutchinson, A.(1994). The virtues and shortcomings of parochialism: conserving species that are locally rare, but globally common. Conservation Biology 8: 1163 1165.DOI:10.1046/j.15231739.1994.08041163.x.

Huston, M. A. (1994). Biological Diversity-The coexistence of species on changing landscape. Cambridge University Press, Cambridge

Jain, S. K. (1991).Dictionary of Indian folk medicine and ethnobotany. Deep Publications, New Delhi, India.

Joshi,H. C. and Samant, S. S.(2004). Assessment of forest vegetation and conservation priorities of communities in a part of Nanda Devi Biosphere Reserve, West Himalaya. Part 1.International Journal of Sustainable Development of World 11(3): 326-336. DOI: $10.1080 / 13504500409469835$.

Kala, C. P. (2004). Community composition, species diversity, and secondary succession in grazed and ungrazed alpine meadows of the West Himalaya, India. International Journal of Field Studies 2(1).

Kala, C. P., Rawat, G. S. and Uniyal, V. K.(1998).Ecology and conservation of the Valley of Flowers National Park, Garhwal Himalaya. Report, Wildlife Institute of India, Dehradun.

Krupnick, G. A.(2013). Conservation of Tropical Plant Biodiversity: What Have We Done, Where Are We Going?Biotropica 45(6): 693-708. DOI: 10.1111/btp.12064.

Lal, M.(2007).Assessment of diversity and conservation status of plants in Kais Wildlife Sanctuary of Himachal Pradesh in NorthWestern Himalaya. Ph.D. Thesis, Kumaun University Nainital.

Levine, M. J., Vila, M., Antonio,C. M. D., Dukes, J. S., Grigulis, K. and Lavorel, S.(2003). Mechanisms underlying the impacts of exotic plant invasions. The Royal Society 270:775-781. DOI: 10.1098/rspb.2003.2327.

Lundberg, P., Ranta,E. and Kaitala, V. (2000). Species loss leads to community closure. Ecology Letters 3: 465-468. DOI: 10.1111/j.1461-0248.2000.00170.x.
Millennium Ecosystem Assessment (MA). 2005. Ecosystems and Human Well-Being: Synthesis. Island Press, Washington. 155pp.

Mittermeier, R. A., Gil, P. L., Hoffman,M., Pilgrim, J., Brooks, T., Mittermeier, C. G., Lamoreux, J. and Fonseca, G. A. B. D.(2004).Hotspots Revisited: Earth's Biologically Richest and Most Endangered Terrestrial Ecoregions. Conservation International, Washington, pp 392.

Monzón, J., Moyer-Horner, L. and Palamar, M. B.(2011). Climate change and species range dynamics in protected areas. BioScience 61: 752761. DOI: 10.1525/bio.2011.61.10.5.

Mora, C., Tittensor, D. P., Adl, S., Simpson, A. G. B. and Worm, B.(2011). How many species are there on earth and in the ocean? PLoS Biology9:1100-1127.

DOI: 10.1371/journal.pbio.1001127.

Myers, N.(1993).Biodiversity and the precautionary principle. Ambio 22 (2-3): 74-79. http://www.jstor.org/stable/4314050.

Nayar, M. P. and Sastry, A. R. K.(1987, 1988, 1990).Red Data Book of Indian Plants, Vol. I-III. Botanical Survey of India, Calcutta.

Novasek, M. J. and Cleland, E. E.(2001). The current biodiversity extinction event: Scenarios for mitigation and recovery. Science 98(10): 54665470. DOI: 10.1073/pnas.091093698.

Pandey, S. and Well, M. P.(1997). Eco-development planning at India's great Himalayan National Park for biodiversity conservation and participatory rural development.Biodiversity and Conservation 6: 1277-1292. DOI:10.1023/b:bioc.0000034013.15097.23.

Pangtey, Y. P. S. and Samant, S. S.(1988). Observations on the threatened, rare and endangered flowering plants and ferns in the flora of Kumaun Himalaya. Advances in Forestry Research in India 3: 65-74.

Rana, M. S. and Samant, S. S.(2010). Threat categorization and conservation priortisation of floristic diversity in the Indian Himalayan region: A state of art approach from Manali Wildlife Sanctuary. Journal of Nature Conservation 18(3): 159-168. DOI: 10.1016/j.jnc.2009.08.004.

Rawal, R. S. and Dhar, U.(1997). Sensitivity of timberline flora in Kumaun Himalaya, India: conservation implications. Arctic, Antarctic and Alpine Research 29(1): 112-121. DOI: 10.2307/1551841.

Sala, O. E., Chapin, F. S., Armesto, J. J., Berlow, E., et al.,(2000) Global biodiversity scenarios for the year 2100. Science 287: 1770-1774.DOI: 10.1126/science.287.5459.1770.

Samant, S. S. (1999). Diversity, nativity and endemism of vascular plants in a part of Nanda Devi Biosphere Reserve in west Himalaya. Himalayan Biosphere Reserves (Biannual Bulletin), 1(1\&2): 1-28. 
Samant, S. S., Butola, J. S. and Sharma, A. (2007). Assessment of Diversity, Distribution, Conservation Status and Preparation of Management Plan for Medicinal Plants in the Catchment Area of Parbati Hydroelectric Project Stage - III in Northwestern Himalaya. Journal of Mountain Science 4 (1): 34-56. DOI: 10.1007/s11629-007-0034-3.

Samant, S. S. and Dhar, U.(1997). Diversity, endemism and economic potential of wild edible plants of Indian Himalaya. International Journal of Sustainable Development and World Ecology 4: 179-191. DOI: 10.1080/13504509709469953.

Samant, S. S., Dhar, U. and Palni, L. M. S. (1998). Medicinal plants of Indian Himalaya: Diversity Distribution Potential Values. Gyanodaya Prakashan, Nainital.

Samant, S. S., Dhar, U. and Rawal, R. S. (1996).Conservation of rare endangered plants: The context of Nanda Devi Biosphere Reserve. In: Conservation and management of biological resources in Himalaya. Ramakrishnan, P.S., Purohit, A.N., Saxena, K.G., Rao, K.S. and Maikhuri, R.K. (ed.). Oxford \& IBH Publishing Company Private Limited, New Delhi. pp 521545.

Samant, S. S., and Joshi H. C.(2005). Plant diversity and conservation status of Nanda Devi National Park and comparisons with highland National Parks of Indian Himalayan Region. International Journal of Biodiversity Science and Management 1(1): 65-73.

DOI: 10.1080/17451590509618081.

Samant, S. S., Joshi, H. C. and Arya, S. C.(2000). Diversity, nativity and endemism of vascular plants in Pindari area of Nanda Devi Biosphere Reserve-II. Himalayan Biosphere Reserves 2(1\&2): 1-29.

Samant, S. S. Palni, L. M. S. (2000). Diversity, distribution and indigenous uses of essential oil yielding medicinal plants of Indian Himalayan Region. Journal of Medicinal and Aromatic Plant Science 22: 671-684.

Saxena, A. K. and Singh, J. S.(1982). A phytosociological analysis of woody species in forest communities of a part of Kumaun Himalaya. Vegetatio 50: 3-22. DOI: 10.1007/bf00120674.

Schmeller, D. S., Bauch, B., Gruber, B., Juskaitis, R., Budrys, E., Babij, V., Lanno, K., Sammul, M., Varga, Z. and Henle, K.(2008). Determination of conservation priorities in regions with multiple political jurisdictions. Biodiversity and Conservation 17: 3623-3630. DOI: 10.1007/s10531-008-9446-9.

Serrill, W. D.(2006).Restoration of native plant on Catalina Island. Native Plants. Vol. Spring: 5-11.

Sharma, E., Chettri, N. and Oli, K. P. (2010). Mountain biodiversity conservation and management: a paradigm shift in policies and practices in the Hindu Kush-Himalayas. Ecological Research 25: 909-923. DOI: 10.1007/s11284-010-0747-6.

Sharma, P.(2013).Ecological assessment of floristic diversity and possible impacts of hydropower projects in Kullu district of Himachal Pradesh, North Western Himalaya. Ph. D. Thesis. Kumaun university Nainital.

Silva, A. C. O. and Albuquerque, U. P.(2005). Woody medicinal plants of the caatinga in the state of Pernambuco (Northeast Brazil). Acta Botanica Brasilica 19(1): 17-26. DOI: 10.1590/s010233062005000100003.

Singh, J. S.(2002). The biodiversity crisis: A multifaceted review. Current Science 82 (6): 638647.

Singh, J. S. and Singh, S. P.(1992). Forest of Himalaya: Structure, Functioning and Impact of Man. Gyanodya Prakashan, Nainital.

Tali, B. A., Ganie, A.H., Nawchoo, I. A., Wani,A. A. and Reshi, Z. A.(2015). Assessment of threat status of selected endemic medicinal plants using IUCN regional guidelines: A case study from Kashmir Himalaya. Journal of Nature Conservation 23: 80-89. DOI: 10.1016/j.jnc.2014.06.004.

Tarraso'n, D., Urrutia, J. T., Ravera, F., Herrera, E., Andre's, P. and Espelta, J. M.(2010). Conservation status of tropical dry forest remnants in Nicaragua: Do ecological indicators and social perception tally? Biodiversity and Conservation 19: 813-827. DOI: 10.1007/s10531-009-9736-x.

Ved, D. K., Kinhal, G. A., Ravikumar, K., Prabhakaran, V., Ghate, U., Shankar, R.V. and Indresha, J. H. (2003).Conservation Assessment and Management Prioritization for the Medicinal Plants of Jammu and Kashmir, Himachal Pradesh and Uttaranchal: Shimla CAMP Report. FRLHT. Bangalore.

Ved, D. K., Kinhal, G.A., Ravikumar, K., Vijaya Shankar, R. and Haridasan, K.(2005).Conservation assessment and management prioritization (CAMP) for the wild medicinal plants of North-East India. Medicinal Plant Conservation 11: 40-44.

Vitousek, P. M.(1990). Biological invasions and ecosystem processes: toward an integration of population biology and ecosystem studies. Oikos 57: 7-13. DOI: 10.1007/978-1-4612-4018-1_17.

Zomer, R. J., Xu, J., Wang, M., Trabucco, A. and Li, Z.(2015). Projected impact of climate change on the effectiveness of the existing protected area network for biodiversity conservation within Yunnan Province, China. Biological Conservation 184: 335-345. DOI: 10.1016/j.biocon.2015.01.031. 
Table 2: Status of the threatened plants in NWS.

\begin{tabular}{|c|c|c|c|c|c|c|c|}
\hline \multirow{2}{*}{ Taxa } & \multirow{2}{*}{ Family } & \multirow{2}{*}{ Nativity } & \multirow{2}{*}{$\mathbf{L F}$} & \multirow{2}{*}{$\mathbf{A R}(\mathbf{m})$} & \multirow{2}{*}{ Habitats } & \multicolumn{2}{|c|}{ Status } \\
\hline & & & & & & HP & GB \\
\hline \multicolumn{8}{|l|}{ Critically Endangered (CR) } \\
\hline Aconitum heterophyllum Wall.ex Royle* & Ranunculaceae & Reg Himal & $\mathrm{H}$ & $3000-4100$ & $1,7,8$ & $\mathrm{CR}$ & CR \\
\hline Allium humile Kunth* & Alliaceae & Reg Himal Ind Or & $\mathrm{H}$ & $3200-4000$ & 1,7 & - & - \\
\hline Allium wallichii Kunth & Alliaceae & Reg Himal & $\mathrm{H}$ & $2500-4100$ & 1,7 & - & - \\
\hline Dactylorhiza hatagirea D. Don & Orchidaceae & $\begin{array}{l}\text { Reg Himal Europ Afr } \\
\text { Bor Or }\end{array}$ & $\mathrm{H}$ & $2800-3870$ & 1,7 & $\mathrm{CR}$ & - \\
\hline Habenaria edgeworthii Hook.f. ex Collett* & Orchidaceae & Reg Himal & $\mathrm{H}$ & $1500-3000$ & 1 & - & - \\
\hline Malaxis muscifera (Lindl.) Kuntze & Orchidaceae & Europ & $\mathrm{H}$ & $1800-3200$ & 1,7 & $\mathrm{CR}$ & - \\
\hline Picrorhiza kurrooa Royle & Scrophulariaceae & Reg Himal & $\mathrm{H}$ & $2800-3850$ & $1,2,8$ & EN & - \\
\hline Podophyllum hexandrum Royle & Podophyllaceae & Ind Or As Trop & $\mathrm{H}$ & $2500-3700$ & 1,7 & EN & - \\
\hline \multicolumn{8}{|l|}{ Endangered (EN) } \\
\hline Acer caesium Wall. ex Brandis* & Aceraceae & Reg Himal & $\mathrm{T}$ & $2100-3200$ & $1,2,9$ & - & - \\
\hline Aconitum violaceum Jacq. ex Stapf.* & Ranunculaceae & Reg Himal & $\mathrm{H}$ & $3500-4000$ & $1,7,8$ & $\mathrm{VU}$ & VU \\
\hline Aconitum laeve Royle & Ranunculaceae & Reg Himal & $\mathrm{H}$ & $2700-3000$ & 1,7 & - & - \\
\hline Allium stracheyi Baker* & Alliaceae & Reg Himal & $\mathrm{H}$ & $3600-3800$ & 1 & VU & VU \\
\hline Angelica glauca Edgew. * & Apiaceae & Reg Himal & $\mathrm{H}$ & $2000-2800$ & 1,7 & EN & EN \\
\hline Berberis asiatica Roxb. ex DC. & Berberidaceae & Reg Himal & $\mathrm{Sh}$ & $1200-2000$ & 1,2 & - & - \\
\hline Betula utilis D. Don & Betulaceae & Reg Himal Japon & $\mathrm{T}$ & $2700-3400$ & 8,9 & EN & - \\
\hline $\begin{array}{l}\text { Cinnamomum tamala (Buch.-Ham.) Nees \& } \\
\text { Ebermaeir }\end{array}$ & Lauraceae & Reg Himal & $\mathrm{T}$ & $1000-1500$ & $1,2,3$ & VU & - \\
\hline Euonymus tingens Wall. & Celastraceae & Reg Himal & $\mathrm{T}$ & $1700-2900$ & $1,2,10$ & - & - \\
\hline Fritillaria roylei $\mathrm{Hk}$. & Liliaceae & Reg Himal & $\mathrm{H}$ & $2700-3500$ & 1 & EN & EN \\
\hline Hypericum perforatum L. & Hypericaceae & Europ & $\mathrm{H}$ & $1100-2200$ & $1,2,3,4$ & VU & - \\
\hline $\begin{array}{l}\text { Jurinella macrocephala (Benth. ex Hk. f.) } \\
\text { Aswal \& Malhotra }\end{array}$ & Asteraceae & Reg Himal & $\mathrm{H}$ & $3000-3850$ & 1,7 & EN & - \\
\hline
\end{tabular}




\begin{tabular}{|c|c|c|c|c|c|c|c|}
\hline \multirow{2}{*}{ Taxa } & \multirow{2}{*}{ Family } & \multirow{2}{*}{ Nativity } & \multirow{2}{*}{$\mathbf{L F}$} & \multirow{2}{*}{$\mathbf{A R}(\mathbf{m})$} & \multirow{2}{*}{ Habitats } & \multicolumn{2}{|c|}{ Status } \\
\hline & & & & & & HP & GB \\
\hline Nervilia plicata $\mathrm{L}$. & Orchidaceae & Reg Himal & $\mathrm{H}$ & $1050-1200$ & 5 & - & - \\
\hline Paris polyphylla $\mathrm{Sm}$. & Liliaceae & Reg Himal China & $\mathrm{H}$ & $1200-2200$ & $1,2,3$ & EN & - \\
\hline $\begin{array}{l}\text { Rhodiola heterodonta (Hk. \& Th.) A. } \\
\text { Boriss.* }\end{array}$ & Crassulaceae & Reg Himal & $\mathrm{H}$ & $2930-4000$ & $1,2,3,8$ & VU & VU \\
\hline $\begin{array}{l}\text { Taxus baccata ssp. wallichiana (Zucc.) } \\
\text { Pilger }\end{array}$ & Taxaceae & Reg Himal & $\mathrm{T}$ & $2500-3300$ & 1,2 & $\mathrm{EN}$ & - \\
\hline Trillium govanianum Wall. ex D.Don & Trillidiaceae & Reg Himal & $\mathrm{H}$ & $2300-3300$ & 1,10 & - & - \\
\hline \multicolumn{8}{|l|}{ Vulnerable (VU) } \\
\hline Acer cappadocicum Gled. & Aceraceae & Asia Minor & $\mathrm{T}$ & $2600-3000$ & 1,3 & - & - \\
\hline Acer oblongum Wall. & Aceraceae & Reg Himal & $\mathrm{T}$ & $1400-1950$ & 1,9 & - & - \\
\hline Acorus calamus $\mathrm{L}$. & Araceae & Reg Bor Temp & $\mathrm{H}$ & $1300-2200$ & 5,11 & - & - \\
\hline Aerva sanguinolenta (L.) Bl. & Amaranthaceae & Java & $\mathrm{H}$ & $1000-1200$ & 1,2 & - & - \\
\hline Aralia cachemirica Decne.* & Araliaceae & Reg Himal & $\mathrm{H}$ & $2500-3050$ & 2,3 & - & - \\
\hline Asparagus racemosus Wild. & Asparagaceae & $\begin{array}{l}\text { Ind Or Afr Trop } \\
\text { Austr }\end{array}$ & $\mathrm{H}$ & $1300-1700$ & $1,2,4$ & - & - \\
\hline Berberis aristata DC.* & Berberidaceae & Ind Or & $\mathrm{Sh}$ & $1200-2800$ & 10 & - & - \\
\hline Bergenia ciliata (Hew.) Stercb.* & Saxifragaceae & Reg Himal & $\mathrm{H}$ & $2000-3500$ & 2,3 & - & - \\
\hline Betula alnoides Buch.-Ham. ex D.Don & Betulaceae & Reg Himal Japon & $\mathrm{T}$ & $1800-2500$ & $1,2,4$ & - & - \\
\hline Boschniakia himalaica Hk.f. \& Th. ex Hk.f. & Orobanchaceae & Reg Himal & $\mathrm{H}$ & $2700-3300$ & 1 & - & - \\
\hline Bupleurum atroviolaceum (Schulz) Nasir* & Apiaceae & Pak Himal & $\mathrm{H}$ & $2100-3000$ & $1,7,8$ & - & - \\
\hline Campanula latifolia $\mathrm{L}$. & Campanulaceae & Europ Or As Temp & $\mathrm{H}$ & $2600-3500$ & $2,3,8$ & - & - \\
\hline Clintonia udensis Trautv. \& Mey. & Liliaceae & Siberia Japon & $\mathrm{H}$ & $3200-4000$ & $1,7,10$ & - & - \\
\hline Corydalis govaniana Wall. & Fumariaceae & Reg Himal & $\mathrm{H}$ & $3000-4000$ & $1,2,7$ & - & - \\
\hline Corylus jacquemontii L.* & Corylaceae & $\begin{array}{l}\text { Europe Or As Min } \\
\text { Himal }\end{array}$ & $\mathrm{T}$ & $2490-2900$ & 1,5 & - & - \\
\hline Deeringia amaranthoides (Lam.) Merr. & Amaranthaceae & As et Afr Trop & $\mathrm{Sh}$ & $1000-1400$ & 1,2 & - & - \\
\hline $\begin{array}{l}\text { Delphinium denudatum Wall. ex Hk. f. \& } \\
\text { Th.* }\end{array}$ & Ranunculaceae & Reg Himal & $\mathrm{H}$ & $2000-2600$ & $1,2,5$ & - & - \\
\hline Desmodium gangeticum (L.) DC. & Fabaceae & As Trop Austr & $\mathrm{Sh}$ & $1000-1500$ & $1,2,3$ & - & - \\
\hline
\end{tabular}




\begin{tabular}{|c|c|c|c|c|c|c|c|}
\hline \multirow{2}{*}{ Taxa } & \multirow{2}{*}{ Family } & \multirow{2}{*}{ Nativity } & \multirow{2}{*}{$\mathbf{L F}$} & \multirow{2}{*}{$\mathbf{A R}(\mathbf{m})$} & \multirow{2}{*}{ Habitats } & \multicolumn{2}{|c|}{ Status } \\
\hline & & & & & & HP & GB \\
\hline Dioscorea deltoidea Wall. & Dioscoreaceae & Ind Or & $\mathrm{H}$ & $950-2500$ & $1,2,3$ & EN & EN \\
\hline Drepanostachyum falcatum (Nees) Keng f. & Poaceae & Reg Himal & $\mathrm{Sh}$ & $1700-2200$ & 1,2 & - & - \\
\hline Engelhardtia spicata Leschen. ex Bl. & Juglandiaceae & Reg Himal Malaya & $\mathrm{T}$ & $1000-1600$ & $1,2,3$ & - & - \\
\hline $\begin{array}{l}\text { Gymnopteris vestita (Wall. ex Moore) } \\
\text { Underwood }\end{array}$ & Hemionitidaceae & - & Fn & $1000-2500$ & $1,2,3$ & - & - \\
\hline Hedychium spicatum $\mathrm{Sm} . *$ & Zingiberaceae & Reg Himal & $\mathrm{H}$ & $1000-2500$ & $1,2,5$ & - & - \\
\hline Heracleum candicans Wall. ex DC. & Apiaceae & Reg Himal & $\mathrm{H}$ & $1500-2800$ & $1,2,4$ & - & - \\
\hline Heracleum wallichii $\mathrm{DC}^{*}$ & Apiaceae & Reg Himal & $\mathrm{H}$ & $3500-4000$ & 1,9 & - & - \\
\hline Herminium monorchis (L.) R.Br. & Orchidaceae & Europ As Bor & $\mathrm{H}$ & $2000-4000$ & $1,5,7$ & - & - \\
\hline Himalayacalamus falconeri Keng f. & Poaceae & Reg Himal & $\mathrm{H}$ & $2000-3000$ & $1,2,4$ & - & - \\
\hline Juglans regia $\mathrm{L} . *$ & Juglandiaceae & Reg Himal As Occ & $\mathrm{T}$ & $1700-3000$ & $1,2,3,9$ & - & - \\
\hline Lagotis cashmeriana Rupr.* & Scrophulariaceae & Reg Himal & $\mathrm{H}$ & $3100-4100$ & $1,3,6,7,8$ & - & - \\
\hline Lannea coromandelica (Houtt. ) Merr. & Anacardiaceae & Ind Or & $\mathrm{T}$ & $980-1300$ & $2,4,5$ & - & - \\
\hline Leycesteria formosa Wall. & Caprifoliaceae & Reg Himal & $\mathrm{H}$ & $1500-2800$ & $1,2,4$ & - & - \\
\hline Malaxis acuminata D. Don & Orchidaceae & Reg Himal & $\mathrm{H}$ & $1600-2500$ & 1 & - & - \\
\hline Melothria heterophylla (Lour.) Cogn. & Cucurbitaceae & As Trop et Sub Trop & $\mathrm{H}$ & $2000-2500$ & $1,2,4,5$ & - & - \\
\hline Morus serrata Roxb. & Moraceae & Reg Himal & $\mathrm{T}$ & $970-2300$ & 2,3 & - & - \\
\hline Nepeta govaniana Benth.* & Lamiaceae & Reg Himal & $\mathrm{H}$ & $1700-2800$ & $1,2,7$ & - & - \\
\hline Olea ferruginea Royle* & Oleaceae & Reg Himal & $\mathrm{T}$ & $1300-1600$ & 2,9 & - & - \\
\hline Osmunda japonica Thunb. & Osmundaceae & - & Fn & $2100-2500$ & 1,9 & - & - \\
\hline Parnassia nubicola Wall. ex Royle* & Parnassiaceae & Reg Himal & $\mathrm{H}$ & $3000-4000$ & $1,7,8$ & - & - \\
\hline Parnassia pusilla Wall. ex Arn. & Parnassiaceae & Bhutan & $\mathrm{H}$ & $2300-3600$ & 1,7 & - & - \\
\hline Pellaea nitidula (Wall. ex Hk.) Hk. et Baker & Sinopteridaceae & - & Fn & $2000-2300$ & $1,2,6$ & - & - \\
\hline Phegopteris connectilis Watt. & Thelypteridaceae & - & Fn & $2600-3050$ & $1,3,5,7$ & - & - \\
\hline Phoenix humilis (L.) Cav. & Arecaceae & Ind Or & $\mathrm{T}$ & $1000-1500$ & 5 & - & - \\
\hline Phymatopteris stracheyi (Ching) Pic. Serm. & Polypodiaceae & - & Fn & $2500-3300$ & $1,2,4$ & - & - \\
\hline Pistacia integerrima (Stewart) Rech. f. & Anacardiaceae & Egypt Persia Reg & $\mathrm{T}$ & $1000-2200$ & 1,2 & - & - \\
\hline
\end{tabular}




\begin{tabular}{|c|c|c|c|c|c|c|c|}
\hline \multirow{2}{*}{ Taxa } & \multirow{2}{*}{ Family } & \multirow{2}{*}{ Nativity } & \multirow{2}{*}{$\mathbf{L F}$} & \multirow{2}{*}{$\mathbf{A R}(\mathbf{m})$} & \multirow{2}{*}{ Habitats } & \multicolumn{2}{|c|}{ Status } \\
\hline & & & & & & HP & GB \\
\hline & & Himal & & & & & \\
\hline Pleurospermum angelicoides (DC.) Cl. & Apiaceae & Reg Himal & $\mathrm{H}$ & $3000-3650$ & $1,2,7$ & - & - \\
\hline Pleurospermum brunonis $\mathrm{Cl} . *$ & Apiaceae & Reg Himal & $\mathrm{H}$ & $3000-3650$ & 1,7 & - & - \\
\hline Pleurospermum candollii (DC.) Cl.* & Apiaceae & Reg Himal & $\mathrm{H}$ & $3000-3850$ & $1,7,8$ & - & - \\
\hline Polygonatum multiflorum (L.) All. & Liliaceae & Europ As Bor & $\mathrm{H}$ & $3000-4000$ & 1,2 & VU & - \\
\hline Polygonatum verticillatum (L.) All. & Liliaceae & Europ As Bor & $\mathrm{H}$ & $1700-3500$ & $1,2,3$ & VU & - \\
\hline Rheum australe D.Don* & Polygonaceae & Reg Himal & $\mathrm{H}$ & $2500-3300$ & $1,7,8$ & - & - \\
\hline Rheum moorcroftianum Royle* & Polygonaceae & Reg Himal & $\mathrm{H}$ & $3500-4100$ & $1,7,8$ & EN & - \\
\hline Rhododendron lepidotum Wall. & Ericaceae & Reg Himal & Sh & $2700-3100$ & $7,8,10$ & VU & - \\
\hline Rhus cotinus $\mathrm{L}$. & Anacardiaceae & $\begin{array}{l}\text { Mediter Or Reg } \\
\text { Himal China }\end{array}$ & $\mathrm{Sh}$ & $1100-1800$ & $1,2,3$ & - & - \\
\hline Rhus wallichii Hk.f.* & Anacardiaceae & Reg Himal & $\mathrm{T}$ & $1500-2400$ & $1,2,4$ & - & - \\
\hline Ribes alpestre Wall. ex Decne. & Grossulariaceae & China Xizang & $\mathrm{Sh}$ & $2000-3300$ & $1,2,5,10$ & - & - \\
\hline Roylea cinerea Wall. Ex Benth.* & Lamiaceae & Reg Himal & $\mathrm{Sh}$ & $1200-3700$ & $1,3,7,9$ & VU & $\mathrm{VU}$ \\
\hline Salvia lanata Roxb.* & Lamiaceae & Reg Himal & $\mathrm{H}$ & $1400-2500$ & $1,2,3,10$ & - & - \\
\hline Sambucus adnata Wall. & Caprifoliaceae & Reg Himal & $\mathrm{H}$ & $2500-2710$ & 1,3 & - & - \\
\hline Saussurea taraxacifolia Wall. ex DC. & Asteraceae & Reg Himal & $\mathrm{H}$ & $3100-3600$ & $1,7,8$ & - & - \\
\hline Skimmia laureola Sieb. \& Zucc. ex Walp. & Rutaceae & Reg Himal & Sh & $1200-2800$ & $1,2,10$ & - & - \\
\hline Sorbus lanata (D.Don) Schauer & Rosaceae & Reg Himal & $\mathrm{T}$ & $2100-3000$ & 1,2 & - & - \\
\hline Swertia cordata Wall.* & Gentianaceae & Reg Himal & $\mathrm{H}$ & $2700-3500$ & $1,2,7$ & - & - \\
\hline Swertia angustifolia Ham. ex D. Don & Gentianaceae & Reg Himal & $\mathrm{H}$ & $1500-3000$ & $1,6,7,8$ & - & - \\
\hline Swertia cilliata (G.Don) Burtt* & Gentianaceae & Reg Himal & $\mathrm{H}$ & $2700-4000$ & $1,2,7,8$ & - & - \\
\hline Symplocos chinensis (Lour.) Decne. & Symplocaceae & Japon & $\mathrm{T}$ & $1200-2600$ & 1,2 & - & - \\
\hline Tanacetum dolichophyllum Kitamura & Asteraceae & Mexico & $\mathrm{H}$ & $3000-4000$ & 1,7 & - & - \\
\hline Thamnocalamus spathiflora (Trin.) Munro* & Poaceae & Reg Himal & Sh & $1000-3000$ & $1,2,3,4$ & - & - \\
\hline Toona ciliata $\mathrm{M}$. Roem. & Meliaceae & Malaya Austr & $\mathrm{T}$ & $1000-1500$ & 1 & - & - \\
\hline Trichosanthes tricuspidata Lour. & Cucurbitaceae & China & $\mathrm{H}$ & $1300-2000$ & 1,2 & - & - \\
\hline
\end{tabular}




\begin{tabular}{|c|c|c|c|c|c|c|c|}
\hline \multirow{2}{*}{ Taxa } & \multirow{2}{*}{ Family } & \multirow{2}{*}{ Nativity } & \multirow{2}{*}{$\mathbf{L F}$} & \multirow{2}{*}{$\mathbf{A R}(\mathbf{m})$} & \multirow{2}{*}{ Habitats } & \multicolumn{2}{|c|}{ Status } \\
\hline & & & & & & HP & GB \\
\hline Valeriana hardwickii Wall. & Valerianaceae & Reg Himal Malaya & $\mathrm{H}$ & $2000-3050$ & $1,7,8$ & - & - \\
\hline Valeriana jatamansi Jones & Valerianaceae & Reg Himal & $\mathrm{H}$ & $1400-3000$ & $1,7,8$ & VU & - \\
\hline Vanda cristata Lindl. & Orchidaceae & Reg Himal As Trop & $\mathrm{H}$ & $1300-2100$ & 1 & - & - \\
\hline Viburnum grandiflorum Wall. ex DC.* & Caprifoliaceae & Reg Himal & Sh & $2500-3000$ & $1,2,10$ & - & - \\
\hline Viburnum mullaha Buch.-Ham. ex D. Don & Caprifoliaceae & Reg Himal & $\mathrm{Sh}$ & $1800-2500$ & $1,2,3,10$ & - & - \\
\hline Vincetoxicum hirudinaria Medik. & Asclepiadaceae & Europ Reg Cauc & $\mathrm{H}$ & $1500-2800$ & $1,2,7$ & - & - \\
\hline Zanthoxylum armatum DC. & Rutaceae & Reg Himal China & Sh & $1000-2500$ & $2,4,10$ & EN & - \\
\hline Zingiber chrysanthum Ros. & Zingiberaceae & Reg Himal & $\mathrm{H}$ & $1200-1700$ & 1,5 & - & - \\
\hline \multicolumn{8}{|l|}{ Near Threatened } \\
\hline Acer acuminatum Wall. ex D.Don* & Aceraceae & Reg Himal & $\mathrm{T}$ & $2900-3100$ & 1,9 & - & - \\
\hline Aechmanthera gossypina Nees & Acanthaceae & Ind Or & $\mathrm{Sh}$ & $1000-2200$ & 1,4 & - & - \\
\hline Aesculus indica Coleb. ex Wall.* & Hippocastanaceae & Reg Himal & $\mathrm{T}$ & $1500-2800$ & $1,2,3,4$ & - & - \\
\hline Agave angustifolia Haw. & Agavaceae & Mexico & $\mathrm{H}$ & $1300-1600$ & 2,4 & - & - \\
\hline Ajugabracteosa Wall. ex Benth. & Lamiaceae & Afr Trop Ind Or As & $\mathrm{H}$ & $1000-2500$ & $1,2,3,4$ & - & - \\
\hline Alangium chinense (Lour.) Harms. & Cornaceae & Ind Or China Japon & $\mathrm{T}$ & $1500-2200$ & $1,2,5$ & - & - \\
\hline Albizia odoratissima (L.f.) Benth. & Mimosaceae & As Afr Trop & $\mathrm{T}$ & $1000-1500$ & 2 & - & - \\
\hline Anemone vitifolia Buch-Ham & Ranunculaceae & Reg Himal & $\mathrm{H}$ & $1600-2800$ & $1,4,8$ & - & - \\
\hline Aquilegia pubiflora Wall. ex Royle* & Ranunculaceae & Ind Or & $\mathrm{H}$ & $1600-2600$ & 1,5 & - & - \\
\hline Arenaria pulvinata Edgew. & Caryophyllaceae & Reg Himal & $\mathrm{H}$ & $3300-3600$ & $2,8,9$ & - & - \\
\hline Artemisia roxburghiana Bess.* & Asteraceae & Reg Himal & $\mathrm{H}$ & $1000-2700$ & $1,2,4,5$ & - & - \\
\hline Asclepias curassavica $\mathrm{L}$. & Asclepiadaceae & Am Austr & $\mathrm{Sh}$ & $980-1200$ & 1 & - & - \\
\hline Asplenium trichomanes $\mathrm{Cl}$. & Aspleniaceae & Japon China & Fn & $1000-3000$ & 1,9 & - & - \\
\hline Astragalus chlorostachys Lindl* & Fabaceae & Reg Himal & $\mathrm{Sh}$ & $1500-2500$ & 1,3 & - & - \\
\hline Astragalus himalayanus Klotz.* & Fabaceae & Reg Himal & $\mathrm{H}$ & $3000-4000$ & 7,8 & - & - \\
\hline Bauhinia vahlii Wight \& Arn. & Caesalpiniaceae & Ind Or & $\mathrm{Sh}$ & $970-1300$ & $2,3,4$ & - & - \\
\hline Bauhinia variegata $\mathrm{L}$ & Caesalpiniaceae & Ind Or Burma China & $\mathrm{T}$ & $950-1400$ & $1,2,10$ & - & - \\
\hline Berberis lycium Royle* & Berberidaceae & Reg Himal & $\mathrm{Sh}$ & $1000-2700$ & $1,2,4,8$ & - & - \\
\hline
\end{tabular}




\begin{tabular}{|c|c|c|c|c|c|c|c|}
\hline \multirow{2}{*}{ Taxa } & \multirow{2}{*}{ Family } & \multirow{2}{*}{ Nativity } & \multirow{2}{*}{$\mathbf{L F}$} & \multirow{2}{*}{$\mathbf{A R}(\mathbf{m})$} & \multirow{2}{*}{ Habitats } & \multicolumn{2}{|c|}{ Status } \\
\hline & & & & & & HP & GB \\
\hline Bergenia stracheyi (Hk. f. \& Th.) Engl.* & Saxifragaceae & Reg Himal & $\mathrm{H}$ & $2700-3650$ & 3,9 & VU & - \\
\hline $\begin{array}{l}\text { Boenninghausenia albiflora (Hk.f.) } \\
\text { Reichenb.ex Meissn. }\end{array}$ & Rutaceae & Reg Himal Japon & $\mathrm{H}$ & $1200-2800$ & 1,2 & - & - \\
\hline Buddleja crispa Benth. & Loganiaceae & Reg Himal Burma & $\mathrm{Sh}$ & $1700-2800$ & $1,2,5,9$ & - & - \\
\hline Bupleurum candolii Wall.ex DC.* & Apiaceae & Reg Himal & $\mathrm{H}$ & $2700-3500$ & $1,7,8$ & - & - \\
\hline Bupleurum hamiltonii Balakr & Apiaceae & Reg Himal & $\mathrm{H}$ & $1900-2500$ & 1,3 & - & - \\
\hline Calanthe tricarinata Lindl. & Orchidaceae & Reg Himal & $\mathrm{H}$ & $2000-3300$ & 1,2 & - & - \\
\hline Caltha palustris L.* & Ranunculaceae & Ind Or & $\mathrm{H}$ & $2000-2600$ & 1,11 & - & - \\
\hline Carissa opaca Stapf. ex Haines & Apocynaceae & Reg Himal & $\mathrm{Sh}$ & $1000-1500$ & $1,2,4$ & - & - \\
\hline Carpinus viminea Lindl. & Corylaceae & Reg Himal & $\mathrm{T}$ & $1500-2200$ & $1,2,4,5$ & - & - \\
\hline Centipeda minima (L.) A.Br. \& Asch. & Asteraceae & $\begin{array}{l}\text { As et Austr Trop Ins } \\
\text { Pacif }\end{array}$ & $\mathrm{H}$ & $1300-1700$ & $1,2,4,9$ & - & - \\
\hline $\begin{array}{l}\text { Cerastium fontanum Baumg. subsp. } \\
\text { membranaceum (Edgew. \& Hook.f. ) }\end{array}$ & Caryophyllaceae & Europ & $\mathrm{H}$ & $2500-4000$ & $2,4,9$ & - & - \\
\hline Ceropegia wallichii Wight & Asclepiadaceae & Reg Himal & $\mathrm{H}$ & $2500-2900$ & 1,2 & - & - \\
\hline Chaerophyllum acuminatum Lindl. & Apiaceae & Reg Himal & $\mathrm{H}$ & $1800-3100$ & 1,2 & - & - \\
\hline Chaerophyllum reflexum Lindl. & Apiaceae & Reg Himal & $\mathrm{H}$ & $2200-3000$ & $1,2,4$ & - & - \\
\hline Chaerophyllum villosum Wall. ex DC.* & Apiaceae & Reg Himal & $\mathrm{H}$ & $2000-3000$ & $1,2,4$ & - & - \\
\hline Cheilanthes acrostica Tod. & Sinopteridaceae & - & $\mathrm{Fn}$ & $1000-2200$ & 1,5 & - & - \\
\hline Cissus repanda Vahl & Vitaceae & Ind Or & $\mathrm{Sh}$ & $1400-1600$ & 1,2 & - & - \\
\hline Clematis barbellata Edgew.* & Ranunculaceae & Reg Himal & $\mathrm{Sh}$ & $990-2800$ & 2,4 & - & - \\
\hline Clematis buchananiana DC. & Ranunculaceae & Reg Himal & $\mathrm{Sh}$ & $1500-3300$ & 2,4 & - & - \\
\hline Clematis graveolens Lindl. & Ranunculaceae & Reg Himal & $\mathrm{Sh}$ & $2000-3000$ & $2,3,4,10$ & - & - \\
\hline Clematis montana Buch.-Ham. ex DC. & Ranunculaceae & Reg Himal & $\mathrm{Sh}$ & $1000-2300$ & 3,10 & - & - \\
\hline Colocasia affinis Schott & Araceae & Reg Himal & $\mathrm{H}$ & $1200-1700$ & 1,2 & - & - \\
\hline Coniogramme affinis (Wall.) Hieron & Hemionitidaceae & - & Fn & $2000-3000$ & $1,7,8$ & - & - \\
\hline Coniogramme falcata Salomon & Hemionitidaceae & - & Fn & $2000-2800$ & 1,8 & - & - \\
\hline
\end{tabular}




\begin{tabular}{|c|c|c|c|c|c|c|c|}
\hline \multirow{2}{*}{ Taxa } & \multirow{2}{*}{ Family } & \multirow{2}{*}{ Nativity } & \multirow{2}{*}{$\mathbf{L F}$} & \multirow{2}{*}{$\mathbf{A R}(\mathbf{m})$} & \multirow{2}{*}{ Habitats } & \multicolumn{2}{|c|}{ Status } \\
\hline & & & & & & HP & GB \\
\hline Coniogramme intermedia Hieron. & Hemionitidaceae & - & Fn & & 1,7 & - & - \\
\hline Coriaria nepalensis Wall. & Coriariaceae & Reg Himal China & $\mathrm{Sh}$ & $1700-2400$ & $2,4,10$ & - & - \\
\hline Cornus capitata Wall. & Cornaceae & Reg Himal & $\mathrm{T}$ & $1200-2300$ & $1,2,4$ & - & - \\
\hline Corydalis cashmeriana Royle* & Fumariaceae & Reg Himal & $\mathrm{H}$ & $2800-3800$ & $1,2,6$ & - & - \\
\hline Corydalis cornuta Royle & Fumariaceae & Reg Himal & $\mathrm{H}$ & $2400-3500$ & $1,2,7,8$ & - & - \\
\hline Corydalis vaginans Royle & Fumariaceae & Reg Himal & $\mathrm{H}$ & $2500-2800$ & $1,2,7,8$ & - & - \\
\hline Cotoneaster bacillaris Wall. ex Lindl.* & Rosaceae & Reg Himal & Sh & $1700-3200$ & $1,2,3,8$ & - & - \\
\hline Cryptogramma stellerii (Gmel.) Prantl & Cryptogrammaceae & - & Fn & $2700-4000$ & $1,3,9$ & - & - \\
\hline Cryptolepis buchananii Roem. \& Schultes & Asclepiadaceae & Ind Or & $\mathrm{Sh}$ & $1300-1800$ & 1,3 & - & - \\
\hline Cyathula capitata Moq. & Amaranthaceae & Reg Himal & $\mathrm{H}$ & $1200-2600$ & 1,4 & - & - \\
\hline Cyathula tomentosa (Roth) Moq. & Amaranthaceae & Reg Himal & Sh & $1000-2400$ & 2,3 & - & - \\
\hline Cystopteris fragilis (L.) Bernh. & Athyriaceae & Ind Or & Fn & $2500-3500$ & $1,7,9$ & - & - \\
\hline Dianthus angulatus Royleex Benth. & Caryophyllaceae & Reg Himal & $\mathrm{H}$ & $2400-3550$ & 2,7 & - & - \\
\hline Dioscorea belophylla (Prain) Haines & Dioscoreaceae & Ind Trop & $\mathrm{H}$ & $1000-1700$ & 1,2 & - & - \\
\hline Dioscorea bulbifera $\mathrm{L}$. & Dioscoreaceae & As Trop & $\mathrm{H}$ & $1000-2100$ & 1,2 & - & - \\
\hline Diplazium spectabile Ching. & Athyriaceae & - & Fn & $1800-2400$ & 1,5 & - & - \\
\hline Dryopteris cochleata (D. Don) C. Chr. & Dryopteridaceae & - & Fn & $1300-1600$ & $1,2,4$ & - & - \\
\hline Dryopteris panda (C.B. Clarke) Chr. & Dryopteridaceae & - & Fn & $2000-2500$ & $1,2,4,5$ & - & - \\
\hline Elaeagnus conferta Wall. ex Royle & Elaeaganaceae & Ind Or & $\mathrm{Sh}$ & $1000-2600$ & $1,2,4$ & - & - \\
\hline Epipactis helleborine (L.) Crantz & Orchidaceae & Reg Himal & $\mathrm{H}$ & $2500-3650$ & 1 & - & - \\
\hline Euonymus fimbriatus Wall. & Celastraceae & Reg Himal & $\mathrm{T}$ & $1200-2800$ & $1,2,4,10$ & - & - \\
\hline Ficus nemoralis Wall. & Moraceae & Reg Himal & $\mathrm{T}$ & $1000-2000$ & 2 & - & - \\
\hline Geranium wallichianum D.Don ex Sw.* & Geraniaceae & Reg Himal & $\mathrm{H}$ & $2500-3100$ & $1,2,7,8$ & - & - \\
\hline Geum roylei Wall. ex Bolle & Rosaceae & Reg Himal Bor Occ & $\mathrm{H}$ & $2600-3500$ & $1,2,7$ & - & - \\
\hline Goodyera fusca Hook.f. & Orchidaceae & Reg Himal & $\mathrm{H}$ & $3000-3900$ & $1,8,9$ & - & - \\
\hline Habenaria pectinata D.Don* & Orchidaceae & Reg Himal & $\mathrm{H}$ & $1400-3500$ & 1 & - & - \\
\hline Herpetospermum pedunculosum (Serin.) Cl. & Cucurbitaceae & Reg Himal & $\mathrm{H}$ & $2200-2500$ & 1,2 & - & - \\
\hline
\end{tabular}




\begin{tabular}{|c|c|c|c|c|c|c|c|}
\hline \multirow{2}{*}{ Taxa } & \multirow{2}{*}{ Family } & \multirow{2}{*}{ Nativity } & \multirow{2}{*}{$\mathbf{L F}$} & \multirow{2}{*}{$\mathbf{A R}(\mathbf{m})$} & \multirow{2}{*}{ Habitats } & \multicolumn{2}{|c|}{ Status } \\
\hline & & & & & & HP & GB \\
\hline Hypoxis aurea Lour. & Hypoxidaceae & China & $\mathrm{H}$ & $1600-2000$ & $1,2,4,6$ & - & - \\
\hline Ilex dipyrena Wall. & Aquifoliaceae & Reg Himal & $\mathrm{T}$ & $1500-2900$ & 1,2 & - & - \\
\hline Ilex excelsa (Wall.) Hk. & Aquifoliaceae & Reg Himal & $\mathrm{T}$ & $1600-2400$ & 1,4 & - & - \\
\hline Jasminum dispermum Wall. & Oleaceae & Reg Himal & $\mathrm{Sh}$ & $1500-2000$ & 2,4 & - & - \\
\hline Jasminum officinale L. & Oleaceae & Ind Bor Occ China & $\mathrm{Sh}$ & $1200-3000$ & 2,4 & - & - \\
\hline Juniperus communis L. & Cupressaceae & $\begin{array}{l}\text { Reg Bor Temp et } \\
\text { Arct }\end{array}$ & $\mathrm{Sh}$ & $2800-3500$ & $1,6,7,8$ & - & - \\
\hline Juniperus indica Bertol. & Cupressaceae & Europ & $\mathrm{Sh}$ & $3000-3600$ & $1,7,8$ & - & - \\
\hline Lonicera myrtillus Hk.f.\& Th. & Caprifoliaceae & Reg Himal & $\mathrm{Sh}$ & $2800-3100$ & $1,2,10$ & - & - \\
\hline Lonicera obovata Royle ex Hk.f.* & Caprifoliaceae & Reg Himal & $\mathrm{Sh}$ & $2700-3100$ & 1,3 & - & - \\
\hline Lonicera quinquelocularis Hardw. & Caprifoliaceae & Reg Himal & Sh & $1000-2500$ & $1,2,9$ & - & - \\
\hline Lyonia ovalifolia (Wall.) Drude & Ericaceae & China & $\mathrm{T}$ & $1200-2700$ & $1,2,3,9$ & - & - \\
\hline Marsdenia lucida Hk.f. \& Thom. & Asclepiadaceae & Reg Himal Nepal & $\mathrm{Sh}$ & $980-1300$ & 1.3 & - & - \\
\hline Meconopsis aculeata Royle* & Papaveraceae & Reg Himal & $\mathrm{H}$ & $3200-3500$ & 7,8 & EN & EN \\
\hline Melia azedarach $\mathrm{L}$. & Meliaceae & Reg Himal & $\mathrm{T}$ & $1000-1500$ & 1 & - & - \\
\hline Meliosma dilleniifolia Walp. & Sabiaceae & Reg Himal & $\mathrm{T}$ & $1800-2600$ & $1,2,4$ & - & - \\
\hline Morina coulteriana Royle* & Morinaceae & Reg Himal & $\mathrm{H}$ & $2960-3455$ & $1,7,8$ & - & - \\
\hline Morina longifolia Wall. ex DC.* & Morinaceae & Reg Himal & $\mathrm{H}$ & $2500-4000$ & $3,7,8$ & - & - \\
\hline Myrica esculenta Buch.-Ham. ex D.Don & Myricaceae & As Trop et Subtrop & $\mathrm{T}$ & $1300-2600$ & $1,2,4,5$ & - & - \\
\hline Neottia listeroides Lindl. & Orchidaceae & Reg Himal & $\mathrm{H}$ & $1800-3600$ & 1 & - & - \\
\hline Ophioglossum petiolatum $\mathrm{Hk}$. & Ophioglossaceae & - & Fn & $2000-2100$ & $1,2,3,4$ & - & - \\
\hline Parnassia asarifolia Vent. & Parnassiaceae & $\begin{array}{l}\text { Temp Amer Afr } \\
\text { Europ As }\end{array}$ & $\mathrm{H}$ & $2400-3000$ & $1,7,8$ & - & - \\
\hline Peristrophe bicalyculata (Retz.) Nees & Acanthaceae & As et Afr Trop & $\mathrm{H}$ & $1000-1600$ & $1,2,4$ & - & - \\
\hline Phyllanthus emblica L. & Euphorbiaceae & As Trop & $\mathrm{T}$ & $970-1400$ & 2,4 & - & - \\
\hline Phytolacca acinosa Roxb. & Phytolaccaceae & Reg Himal China & $\mathrm{H}$ & $1500-3000$ & $1,3,9$ & - & - \\
\hline Pimpinella acuminata (Edgew.) Cl.* & Apiaceae & Reg Himal & $\mathrm{H}$ & $2600-3700$ & $1,3,5$ & - & - \\
\hline Pimpinella diversifolia DC. & Apiaceae & Reg Himal China & $\mathrm{H}$ & $2000-3200$ & $2,3,5$ & - & - \\
\hline
\end{tabular}




\begin{tabular}{|c|c|c|c|c|c|c|c|}
\hline \multirow{2}{*}{ Taxa } & \multirow{2}{*}{ Family } & \multirow{2}{*}{ Nativity } & \multirow{2}{*}{$\mathbf{L F}$} & \multirow{2}{*}{$\mathbf{A R}(\mathbf{m})$} & \multirow{2}{*}{ Habitats } & \multicolumn{2}{|c|}{ Status } \\
\hline & & & & & & HP & GB \\
\hline Plantago himalaica Pilger* & Plantaginaceae & Reg Himal & $\mathrm{H}$ & $1100-3000$ & 1,2 & - & - \\
\hline Polygonatum cirrhifolium (Wall.) Royle & Liliaceae & Reg Himal As Bor & $\mathrm{H}$ & $1800-2300$ & $1,5,10$ & EN & - \\
\hline Polygonum hydropiper L. & Polygonaceae & $\begin{array}{l}\text { Reg Temp Bor et } \\
\text { Aust }\end{array}$ & $\mathrm{H}$ & $980-2400$ & $1,5,11$ & - & - \\
\hline Polygonum recumbens Royle ex Bab. & Polygonaceae & Reg Himal & $\mathrm{H}$ & $1400-3000$ & $2,3,4$ & - & - \\
\hline Polystichum nepalense (Spreng.) C. Chr. & Dryopteridaceae & - & Fn & $2000-2600$ & $1,2,5$ & - & - \\
\hline Polystichum lachenense ( Hook. ) Bedd. & Dryopteridaceae & - & Fn & $2800-3500$ & 1,6 & - & - \\
\hline Potentilla eriocarpa Wall. ex Lehm.* & Rosaceae & Reg Himal & $\mathrm{H}$ & $2600-3600$ & $1,7,8$ & - & - \\
\hline Potentilla fulgens Wall. & Rosaceae & Reg Himal & $\mathrm{H}$ & $2000-3200$ & $1,3,7$ & - & - \\
\hline Primula elliptica Royle & Primulaceae & Reg Himal & $\mathrm{H}$ & $3600-4000$ & 7,8 & - & - \\
\hline Primula involucrata Wall. & Primulaceae & Europ As Bor & $\mathrm{H}$ & $3000-4000$ & 7,8 & - & - \\
\hline Primula rosea Royle* & Primulaceae & Reg Himal & $\mathrm{H}$ & $2500-4000$ & $1,7,8$ & - & - \\
\hline Prunus cerasoides D. Don & Rosaceae & Reg Himal & $\mathrm{T}$ & $2790-3200$ & 1,2 & - & - \\
\hline Pteris pseudoquadriaurita Khullar & Pteridaceae & - & Fn & $1000-2400$ & $1,2,4,5$ & - & - \\
\hline Pteris quadriaurita Retz. & Pteridaceae & - & $\mathrm{Fn}$ & $1000-2400$ & $1,2,5$ & - & - \\
\hline Quercus leucotrichophora A. Camus & Fagaceae & Reg Himal & $\mathrm{T}$ & $1000-2600$ & $1,2,4$ & - & - \\
\hline Rhodiola himalensis (D.Don) S.H. Fu & Crassulaceae & Reg Himal & $\mathrm{H}$ & $3000-4100$ & $1,2,3,8$ & - & - \\
\hline Rhododendron anthopogon D.Don* & Ericaceae & As Bor Reg Himal & Sh & $3000-4100$ & 7,8 & VU & - \\
\hline Rhododendron arboreum $\mathrm{Sm}$. & Ericaceae & $\begin{array}{l}\text { Ind Or Reg Himal } \\
\text { Zeylan }\end{array}$ & $\mathrm{T}$ & $1000-2300$ & $1,2,4$ & - & - \\
\hline Rhododendron campanulatum D.Don* & Ericaceae & Reg Himal & $\mathrm{Sh}$ & $2600-3100$ & $1,2,8,10$ & VU & - \\
\hline Rhus javanica $\mathrm{L}$. & Anacardiaceae & Reg Himal China & $\mathrm{T}$ & $1200-2500$ & 2,4 & - & - \\
\hline Rhus parviflora Roxb. & Anacardiaceae & Reg Himal & Sh & $980-1350$ & 2 & - & - \\
\hline Ribes glaciale Wall. & Grossulariaceae & Reg Himal & $\mathrm{Sh}$ & $2000-3000$ & $1,2,10$ & - & - \\
\hline Ribes himalense Royle ex Decne. & Grossulariaceae & $\begin{array}{l}\text { Europ Afr Bor Reg } \\
\text { Himal }\end{array}$ & Sh & $2700-3100$ & $1,2,3,9,10$ & - & - \\
\hline Rorippa indica (L.) Hiern & Brassicaceae & Ind Or China Malaya & $\mathrm{H}$ & $1800-2300$ & 1,2 & - & - \\
\hline Rosa webbiana Wall. ex Royle* & Rosaceae & Reg Himal & Sh & $2300-3800$ & $2,8,10$ & - & - \\
\hline
\end{tabular}




\begin{tabular}{|c|c|c|c|c|c|c|c|}
\hline \multirow{2}{*}{ Taxa } & \multirow{2}{*}{ Family } & \multirow{2}{*}{ Nativity } & \multirow{2}{*}{$\mathbf{L F}$} & \multirow{2}{*}{$\mathbf{A R}(\mathbf{m})$} & \multirow{2}{*}{ Habitats } & \multicolumn{2}{|c|}{ Status } \\
\hline & & & & & & HP & GB \\
\hline Roscoea purpurea $\mathrm{Sm}$. & Zingiberaceae & Reg Himal Burma & $\mathrm{H}$ & $2000-3000$ & $1,7,10$ & - & - \\
\hline Rubia manjith Roxb. Ex Fleming & Rubiaceae & $\begin{array}{l}\text { As Trop et Temp Afr } \\
\text { Trop }\end{array}$ & Sh & $2000-2500$ & $1,2,10$ & - & - \\
\hline Rubus paniculatus Sm.* & Rosaceae & Reg Himal & $\mathrm{Sh}$ & $1000-2500$ & $2,4,10$ & - & - \\
\hline Rumex acetosa $\mathrm{L}$. & Polygonaceae & Europ As Borv & $\mathrm{H}$ & $1000-3100$ & $1,2,4,6$ & - & - \\
\hline Salix tetrasperma Roxb. & Salicaceae & Ind Or Malaya & $\mathrm{T}$ & $1500-2300$ & $1,2,3$ & - & - \\
\hline Salix wallichiana Anders. & Salicaceae & Reg Himal & $\mathrm{T}$ & $1500-2800$ & 1,2 & - & - \\
\hline Salvia nubicola Wall. & Lamiaceae & Europ Austr Or & $\mathrm{H}$ & $1400-2200$ & $1,2,10$ & - & - \\
\hline Sanicula elata Buch.-Ham. ex D.Don & Apiaceae & $\begin{array}{l}\text { Europ As Bor Afr } \\
\text { Austr }\end{array}$ & $\mathrm{H}$ & $2300-3200$ & 1,2 & - & - \\
\hline Satyrium nepalense D.Don* & Orchidaceae & Reg Himal & $\mathrm{H}$ & $1500-3200$ & 1,7 & - & - \\
\hline Saussurea atkinsonii $\mathrm{Cl}$ & Asteraceae & Reg Himal & $\mathrm{H}$ & $3200-4100$ & 8,9 & - & - \\
\hline Saussurea albescens (DC.) Sch.-Bip.* & Asteraceae & Reg Himal & $\mathrm{H}$ & $3000-3500$ & 1,3 & - & - \\
\hline Saussurea deltoidea (DC.) Sch.-Bip. & Asteraceae & Reg Himal & $\mathrm{H}$ & $2800-3300$ & $7,8,9$ & - & - \\
\hline Saussurea fastuosa (Decne) Sch.-Bip.* & Asteraceae & Reg Himal & $\mathrm{H}$ & $2800-3300$ & $1,3,7$ & - & - \\
\hline $\begin{array}{l}\text { Saussurea heteromala (D. Don) Hand.- } \\
\text { Mazz. }\end{array}$ & Asteraceae & Reg Himal & $\mathrm{H}$ & $2800-3000$ & $1,7,8$ & - & - \\
\hline Saxifraga sibirica $\mathrm{L}$. & Saxifragaceae & As Bor et Arct & $\mathrm{H}$ & $3000-3850$ & 2,3 & - & - \\
\hline Scrophularia himalensis Royle* & Scrophulariaceae & Reg Himal & $\mathrm{H}$ & $2200-2700$ & $1,2,7$ & - & - \\
\hline Selinum candollii DC.* & Apiaceae & Reg Himal & $\mathrm{H}$ & $2000-4000$ & 1,6 & - & - \\
\hline Selinum tenuifolium Wall.* & Apiaceae & Reg Himal & $\mathrm{H}$ & $2600-3100$ & $1,2,7$ & - & - \\
\hline Selinum vaginatum (Edgew.) Cl. & Apiaceae & Reg Himal & $\mathrm{H}$ & $2600-3100$ & $1,2,4$ & - & - \\
\hline Senecio cappa Buch.-Ham. ex D.Don & Asteraceae & Reg Himal & $\mathrm{H}$ & $2400-2800$ & 7,8 & - & - \\
\hline Sorbus foliolosa (Wall.) Spach* & Rosaceae & Reg Himal & $\mathrm{Sh}$ & $2700-3800$ & 1,10 & - & - \\
\hline Spiranthes sinensis (Pers.) Ames. & Orchidaceae & China As Temp & $\mathrm{H}$ & $1100-2800$ & 1,4 & - & - \\
\hline Stellaria himalayensis Majumdar* & Caryophyllaceae & Reg Himal & $\mathrm{H}$ & $1500-2800$ & 2,9 & - & - \\
\hline Stellaria monosperma D.Don* & Caryophyllaceae & Reg Himal & $\mathrm{H}$ & $1700-2700$ & $1,3,9$ & - & - \\
\hline Strobilanthes wallichii Nees* & Acanthaceae & Reg Himal & $\mathrm{H}$ & $2000-2800$ & $1,3,9$ & - & - \\
\hline
\end{tabular}




\begin{tabular}{|c|c|c|c|c|c|c|c|}
\hline \multirow{2}{*}{ Taxa } & \multirow{2}{*}{ Family } & \multirow{2}{*}{ Nativity } & \multirow{2}{*}{$\mathbf{L F}$} & \multirow{2}{*}{$\mathbf{A R}(\mathbf{m})$} & \multirow{2}{*}{ Habitats } & \multicolumn{2}{|c|}{ Status } \\
\hline & & & & & & $\mathrm{HP}$ & GB \\
\hline Swertia alternifolia Royle & Gentianaceae & Reg Himal & $\mathrm{H}$ & $2800-3300$ & 7,8 & - & - \\
\hline Swertia cuneata D.Don* & Gentianaceae & Reg Himal & $\mathrm{H}$ & $3200-4100$ & 7,8 & - & - \\
\hline Swertia paniculata Wall.* & Gentianaceae & Reg Himal & $\mathrm{H}$ & $2000-3500$ & $1,2,7,8$ & - & - \\
\hline Swertia petiolata D.Don & Gentianaceae & Reg Himal & $\mathrm{H}$ & $3800-4100$ & $1,7,8$ & - & - \\
\hline Thalictrum foliolosum DC.* & Ranunculaceae & Reg Himal & $\mathrm{H}$ & $1700-3300$ & $1,2,3,8$ & - & - \\
\hline Thymus linearis Benth. & Lamiaceae & Europ As et Afr Bor & $\mathrm{H}$ & $2000-3000$ & $\begin{array}{l}1,2,3,4,9,1 \\
0\end{array}$ & - & - \\
\hline Thysanolaena maxima Kuntze & Poaceae & As Trop & $\mathrm{H}$ & $1000-1600$ & $1,2,5$ & - & - \\
\hline Ulmus villosa Brandis ex Gamble* & Ulmaceae & Ind Or As Temp & $\mathrm{T}$ & $2200-2800$ & $1,2,4$ & - & - \\
\hline Ulmus wallichiana Planch.* & Ulmaceae & Ind Or & $\mathrm{T}$ & $1500-2200$ & & - & - \\
\hline Verbena officinalis L. & Verbenaceae & Europ Mediter & $\mathrm{H}$ & $1300-1700$ & $1,2,4$ & - & - \\
\hline Viburnum cotinifolium D.Don & Caprifoliaceae & Am Bor & Sh & $2000-2600$ & $1,2,3,10$ & - & - \\
\hline Viburnum nervosum D.Don* & Caprifoliaceae & Reg Himal & $\mathrm{Sh}$ & $2200-3050$ & $1,2,4,10$ & - & - \\
\hline Woodsia cycloloba Hand.-Mazz. & Woodsiaceae & - & Fn & $3200-3500$ & 1,7 & - & - \\
\hline
\end{tabular}

Abbreviations Used: AR=Altitudinal Range; CR=Critically Endangered; EN=Endangered; Fn=Fern; GB=Global; H=Herb; HP=Himachal Pradesh; LC=Least Concern; LF=Life Form; N=Nativity; R=Rare; Sh=Shrub; SR=Site Representation; T=Tree; VU=Vulnerable; Nativity: Afr=Africa; Alp=Alpine; Amer=America; Amphig= Amphigaea; Arab=Arabia; Arct=Arctic; As=Asia; Austr=Australia;Bor=Borealis; et=And; Europ=Europe;Himal=Himalayan; Ind=Indian; Mediterr=Mediterranean; Min=Minor; Occ=Occidentalis; Or=Orientalis; Pacif=Pacific; Reg=Region; Sibir=Siberia; Temp=Temperate; Trop=Tropical; $\mathbf{1 = S h a d y ~ M o i s t ; ~} \mathbf{2}=$ Dry; $\mathbf{3}=$ Rocky; $\mathbf{4 = D e g r a d e d ; ~} \mathbf{5}=$ Riverine; $\mathbf{6}=$ Camping site; $\mathbf{7 = A l p i n e ~ g r a s s l a n d s ; ~} \mathbf{8 = D r y}$ alpine slope; $\mathbf{9 = B o u l d a r y ;} \mathbf{1 0}=$ Shrublands, $\mathbf{1 1}=$ Marshy; *=Endemic 
